\title{
Morphometric analysis of the watershed of Veloso and Café streams
}

\section{Análise morfométrica da microbacia dos córregos Veloso e do Café}

\author{
Danila Morena FIDELES ${ }^{1}$; Gabriela Trindade PIRES²; Felipe José CERIGNONI ${ }^{3}$; \\ César Vincensi Gabbi TAVARES ${ }^{4}$; Valdemir Antônio RODRIGUES ${ }^{5}$
}

\begin{abstract}
${ }^{1}$ Autor para correspondência; Graduando de Engenharia Florestal; Universidade Estadual Paulista "Júlio de Mesquita Filho"; Departamento de Ciências Florestais; Fazenda Lageado - Rua José Barbosa de Barros, nㅜ 1780, 18.610-307 Botucatu/ SP; fideles.danila@gmail.com

2 Graduando de Engenharia Florestal; Universidade Estadual Paulista "Júlio de Mesquita Filho"; gabriela_tpires@hotmail.com

${ }^{3}$ Graduando de Engenharia Florestal; Universidade Estadual Paulista “Júlio de Mesquita Filho”; fcerignoni@gmail.com

4 Graduando de Engenharia Florestal; Universidade Estadual Paulista "Júlio de Mesquita Filho"; cesarxq@gmail.com

${ }^{5}$ Professor Assistente Doutor; Universidade Estadual Paulista "Júlio de Mesquita Filho"; Departamento de Ciências Florestais; valdemirrodrigues@fca.unesp.br
\end{abstract}

\section{Recebido em: 15-10-2014; Aceito em: 14-10-2015}

\begin{abstract}
The study aimed to perform the morphometric characterization of the watershed of Veloso and Café streams, located in the city of Lençóis Paulista-SP, aiming to demonstrate the possibilities of use of morphometric parameters as supporting elements to definition and development of indicators for environmental management. The methodology was based on the use of satellite images, topographic maps and specialized software (ArcGIS 10.1) by sizing the watershed and calculating the morphometric indices. The watershed is of 4th order and has an area of $25.55 \mathrm{~km}^{2}$ and oval to round shape, indicating a high to medium tendency to floods by torrential rains. On the other hand, drainage density $\left(0.92 \mathrm{~km} \mathrm{~km}^{-2}\right)$, average slope $(4.74 \%)$, maximum altimetric amplitude $(60 \mathrm{~m})$, relief ratio $(0.013)$ and roughness coefficient (4.34) are low indices and point to a slow outflow and good ratio infiltration-runoff, reducing erosion risks.
\end{abstract}

Additional keywords: Geoprocessing, Environmental Management, Watershed Management.

\section{Resumo}

O trabalho teve como objetivo fazer a caracterização morfométrica da microbacia dos Córregos Veloso e do Café, localizada no município de Lençóis Paulista-SP, visando a demonstrar as possibilidades de uso dos parâmetros morfométricos como elementos de suporte à definição e elaboração de indicadores para a gestão ambiental. A metodologia baseou-se no uso de imagens de satélite, cartas topográficas e software especializado (ArcGIS 10.1), procedendo-se ao dimensionamento da microbacia e ao cálculo dos índices morfométricos. A microbacia é de ordem $4^{\underline{a}}$ e possui a área de $25,55 \mathrm{~km}^{2}$ e formato redonda a ovalada, indicando de alta a mediana tendência a enchentes mediante chuvas torrenciais. Por outro lado, a densidade de drenagem $\left(0,92 \mathrm{~km} \mathrm{~km}^{-2}\right)$, declividade média $(4,74 \%)$, amplitude altimétrica máxima $(60 \mathrm{~m})$, razão de relevo $(0,013)$ e o coeficiente de rugosidade $(4,34)$ são índices baixos e apontam para um escoamento lento e boa relação infiltração - deflúvio, diminuindo os riscos à erosão.

Palavras-chave adicionais: Geoprocessamento, Gestão ambiental, Manejo de Bacia Hidrográfica.

\section{Introduction}

In terms of environmental planning, especially when it comes to water management, watershed has been employed as landscape management unit, improving knowledge of soil fragility for uses and occupation. By knowing the morphometric conditions and data obtained from the watershed, reaching future conservation and recovery actions for the entire ecosystem.

Environmental indicators are an important tool to help decision and aim to improve communication between researchers, public managers and society in the discussion of complex issues related to environmental quality (Machado et al., 2011).

In this context, morphometric analysis is a set of procedures that characterize geometrical and environmental system composition aspects, serving as indicators related to the form, structural arrangement and interaction between the watersheds and the network of river channels of a watershed (Christofoletti, 1999), evidencing situations and values that surpass hydrological and geomorphological issues, directly covering environmental issues.

Morphometric characterization of watersheds is of fundamental importance for environmental 
studies, especially when the environment in question is undergoing changes in its water resources, as they play important roles within the ecosystem (Pinto Junior, 2005).

Thus, this paper aims to demonstrate the possibilities of use of morphometric parameters as supporting elements to the definition and development of indicators for environmental management, taking advantage of the use of remote sensing and geoprocessing techniques used to characterize watersheds.

\section{Material and methods}

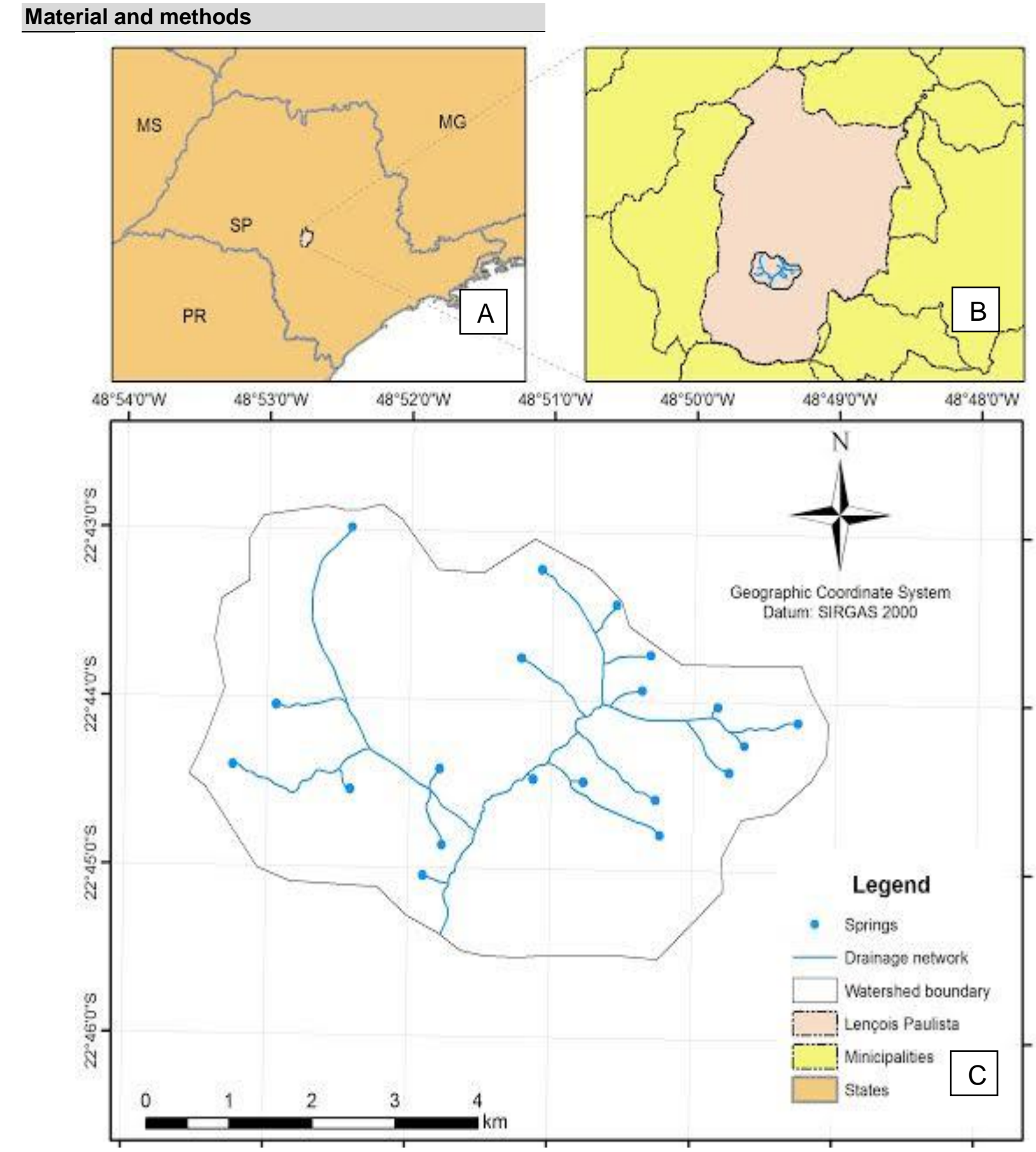

Figure 1 - Location of the study area: State of São Paulo (A), city of Lençóis Paulista (B), watershed of Veloso and Café streams $(\mathrm{C})$.
Study area: the watershed of Veloso and Café streams is fully inserted in the city of Lençóis Paulista/SP (IBGE, scale1: 50,000, sheet PaulistaSF-22-ZBV-1), covering an area of 2,555 ha or $25.55 \mathrm{~km}^{2}$ (Figure 1). The climate of the region is CWa type, high altitude tropical climate according to the Köppen Climate Classification, with temperatures ranging from minimum of $4{ }^{\circ} \mathrm{C}$ (June to August) and maximum of $38^{\circ} \mathrm{C}$ (November to February) and the predominant soil is latosol, according to the Brazilian Soil Classification (Embrapa, 2006). 
Morphometric indices: the map was imported in ArcGIS 10.1 software and geo-referenced for vectorization and for accurately obtaining the dimensional parameters of the watershed, the level curves and drainage network.

Dimensional characteristics of the watershed: the following dimensional parameters were obtained: Height length (Cn); vector distance (Dv), that is, the straight length; the greatest watershed length $(C)$ (orthogonal projection) corresponding to approximately the direction of the main valley, between the estuary and the end point on the line of the watershed; the greatest width of the watershed $(\mathrm{L})$ that cuts across the main valley; the length of the main watercourse $(\mathrm{Cp})$, corresponding to the horizontal representation of the sinuosity of the main river, from the estuary to the spring; Total length of the drainage network $(\mathrm{Cr})$ that follows the sinuosity of the main river and tributary rivers; perimeter of the watershed $(P)$, corresponding to the length of the watershed line surrounding the watershed and; watershed area $(\mathrm{A})$. From the dimensional parameters, variables related to the shape, relief and drainage network of the watershed were calculated.
Characteristics related to the shape: the shape of the watershed is determined by indices that relate known geometric shapes to the watershed, such as shape factor $(\mathrm{Ff})$, compactness coefficient (Kc) and circularity index (Ic).

The shape factor (Ff) associates the shape of the watershed with a rectangle, corresponding to the ratio between the average width and the length of the watershed.

The compactness coefficient $(\mathrm{Kc})$ associates the shape of the watershed with a circle. It is the ratio between the perimeter of the watershed and the circumference of a circle with the same area as the watershed. The calculated number does not depend on the considered area, it depends only on the shape of the watershed.

Simultaneously to the compactness factor, the circularity index (Ic) tends towards unity, as the watershed is closer to circular shape.

The equations used to calculate the characteristics related to the shape of the watershed are described in Table 1.

Table 1 - Morphometric characteristics related to the shape of the watershed of Veloso and Café Streams.

\begin{tabular}{lll}
\hline Parameter & \multicolumn{1}{c}{ Equation } & \multicolumn{1}{c}{ Definition } \\
\hline Shape factor $(\mathrm{Ff})$ & $\mathrm{Ff}=\left(\mathrm{A} / \mathrm{C}^{2}\right)$ & $\mathrm{C}-$ Length $(\mathrm{km})$ \\
& & $\mathrm{A}-$ Area $\left(\mathrm{km}^{2}\right)$ \\
Compactness Coefficient $(\mathrm{Kc})$ & $\mathrm{Kc}=0.28 \times(\mathrm{P} / \sqrt{\mathrm{A}})$ & $\mathrm{P}-$ Perimeter $(\mathrm{m})$ \\
& & $\mathrm{A}-$ Area $\left(\mathrm{m}^{2}\right)$ \\
Circularity Index $(\mathrm{Ic})$ & $\mathrm{Ic}=12.57\left(\mathrm{~A} / \mathrm{P}^{2}\right)$ & $\mathrm{P}-$ Perimeter $(\mathrm{m})$ \\
& & $\mathrm{A}-$ Area $\left(\mathrm{m}^{2}\right)$ \\
\hline
\end{tabular}

Drainage characteristics: variables related to drainage were studied through order $(w)$, drainage density (Dd), maintenance coefficient $(\mathrm{Cm})$, extension of the superficial course of flood (Eps), channel gradient (Gc), and channel sinuosity index (Is).

The order of the watershed $(w)$ is a drainage network classification with the identification and quantification of all channels, according to Strahler (1957). This model assumes that smaller channels are classified by order 1 ; where two order 1 channels meet, an order 2 channel results downstream. In general, where two order $i$ channels meet, an order $I+1$ channel results downstream and; where a lower order channel meets a higher order channel, downstream channel keeps the highest of the two orders (Strahler, 1957).

Drainage density $(\mathrm{Dd})$, calculated according to Horton (1945), corresponds to the ratio between the total length of watershed rivers and their respective area and is expressed in $\mathrm{km}$ of rivers per $\mathrm{km}^{2}$. This parameter reflects the degree of topographical dissection in landscapes designed by fluvial activity, expressing ultimately the available amount of outflow channels.

Maintenance coefficient $(\mathrm{Cm})$ is an index that aims to calculate the minimum area the watershed needs to have to maintain one meter of permanent outflow channel. It is considered one of the most important numerical values for characterizing drainage system by limiting a minimum area required for the development of a channel (Schumm, 1956)

The extension of the superficial course (Eps) of flood water is the average distance traveled by floods before finding a permanent channel (Christofoletti, 1969).

Channel gradient $(G c)$ is the ratio between altitude or maximum height and length of the main channel. This index expresses the ratio between the maximum height and the length of the main channel expressed as a percentage. The purpose is to indicate the slope of the watercourses (Horton, 1945).

River sinuosity index (Is) is a ratio between the real channel length (orthogonal projection) and the vector distance (straight length) between both ends of 
the main channel. Values close to 1.0 indicate that the channel tends to be rectilinear. On the other hand, values greater than 2.0 suggest tortuous channels and intermediate values indicate transitional, regular and irregular shapes. It is known, however, that channel sinuosity is influenced by the load of sediment, the lithological partitioning, geological structure and the channel slope (Lana, 2001).

The equations used to calculate the characteristics related to the shape of the watershed are described in Table 2.

Table 2 - Morphometric characteristics related to the drainage of the watershed of Veloso and Café Streams.

\begin{tabular}{|c|c|c|}
\hline Parameter & Equation & Definition \\
\hline \multirow{2}{*}{ Drainage density (Dd) } & \multirow{2}{*}{$\mathrm{Dd}=\mathrm{Cr} / \mathrm{A}$} & $\mathrm{Cr}$ - Drainage length $(\mathrm{km})$ \\
\hline & & A - Area $\left(\mathrm{km}^{2}\right)$ \\
\hline \multirow{2}{*}{ Channel gradient (Gc) } & \multirow{2}{*}{$\mathrm{Gc}=(\mathrm{AM} / \mathrm{Cp}) \times 100$} & AM - Maximum altitude (m) \\
\hline & & $\mathrm{Cp}$ - Length of the main channel $(\mathrm{m})$ \\
\hline Extension of the superficial course (Eps) & $E p s=(1 / 2 \times D d) \times 1000$ & Dd- Drainage density $\left(\mathrm{km} \mathrm{km}^{-2}\right)$ \\
\hline \multirow{2}{*}{ Sinuosity index (Is) } & \multirow{2}{*}{$\mathrm{Is}=\mathrm{Cp} / \mathrm{Dv}$} & $\mathrm{Cp}$ - Length of the main channel $(\mathrm{m})$ \\
\hline & & Dv - Vector distance $(\mathrm{m})$ \\
\hline Maintenance coefficient $(\mathrm{cm})$ & $\mathrm{Cm}=(1 / \mathrm{Dd})$ & Dd- Drainage density $\left(\mathrm{km} \mathrm{km}^{-2}\right)$ \\
\hline
\end{tabular}

Relief characteristics: average slope (D), maximum (AM), minimum (Am) and average altitude $(\mathrm{Hm})$, altimetric amplitude $(\mathrm{H})$, relief ratio $(\mathrm{Rr})$, roughness coefficient $(\mathrm{Rn})$ were obtained in the evaluation of the relief.

Average slope (D) is the sum of the height length multiplied by the equidistance between heights, divided by the area in $\mathrm{km}^{2}$ (Wisler \& Brater, 1964 quoted by Lima, 1986).

Altimetric amplitude $(\mathrm{H})$ in meters is calculated by the difference between the highest altitude (AM) upstream and the lowest altitude (Am) down- stream of the watershed (Rodrigues et al., 2013).

Relief ratio (Rr), according to Schumm (1956), provides a ratio between the difference of maximum and minimum altitudes in the watershed and the total length of the main channel.

Roughness coefficient (Rn), according to Rocha (1997), is the product of drainage density by average slope.

The equations used to calculate the characteristics related to the relief of the watershed are described in Table 3.

Table 3 - Morphometric characteristics related to the relief of the watershed of Veloso and Café Streams.

\begin{tabular}{lll}
\hline \multicolumn{1}{c}{ Parameter } & \multicolumn{1}{c}{ Equation } & \multicolumn{1}{c}{ Definition } \\
\hline Relief ratio $(\mathrm{Rr})$ & $\mathrm{Rr}=\mathrm{H} / \mathrm{C}$ & $\mathrm{H}-$ Altimetric amplitude $(\mathrm{m})$ \\
& & $\mathrm{C}-$ Length $(\mathrm{m})$ \\
Roughness coefficient $(\mathrm{Rn})$ & $\mathrm{Rn}=(\mathrm{Dd} \times \mathrm{D})$ & $\begin{array}{l}\text { Dd- Drainage density }\left(\mathrm{km} \mathrm{km}^{-2}\right) \\
\mathrm{D}-\text { Average slope }(\%)\end{array}$ \\
& $\mathrm{D}=\left(\sum \mathrm{Cn} \times \Delta \mathrm{H}\right) / \mathrm{A}$ & $\mathrm{Cn}-$ Height length $(\mathrm{m})$ \\
Average slope $(\mathrm{D})$ & $\Delta \mathrm{H}$ - Equidistance between heights $(\mathrm{m})$ \\
\hline
\end{tabular}

\section{Results and discussions}

Dimensional parameters are essential data to characterize and interpret morphometric variables, as well as to analyze the watershed tendency to degradation or environmental conservation. Dimensional parameters of the watershed, relief characteristics and drainage network are described in Table 4.

In Figure 2 and Table 5, all drainage network channels and their respective orders (w) were identified and quantified. 20 channels of 1 st order (Nw1) were identified, i.e. there are 20 perennial springs in the watershed. The watershed is of 4 th order of ramification, according to the Strahler's Classification System (1957).

Topography, geological origin, soil types, vegetation and rainfall intensity, infiltration and water superficial outflow influence drainage density (Rodrigues, 2004). In the presented watershed, drainage density is $0.92 \mathrm{~km}$ of rivers/ $\mathrm{km}^{2}$, with a maintenance coefficient of $1.09 \mathrm{~m} / \mathrm{m}^{2}$. According to Horton's classification (1945), modified by Strahler (1957) and França (1968), it is a low drainage density. Therefore, soil has a low water superficial outflow and hence a high permeability and infiltration of water; just 
as the lower the drainage density is, the greater is the length of rivers. Thus, erosion processes are less intense and, therefore, concerns are minor regarding management practices and riparian forest conservation (Machado et al., 2011).

The extension of the superficial course (Eps) of floods before finding a permanent channel has an average distance of $457.53 \mathrm{~m}$, while Rodrigues et al. ((2013) found an Eps of $531.92 \mathrm{~m}$. The greater the superficial outflow course of rain water, the longer the concentration of flood water, causing minor floods, increasing the tendency to greater conservation of the watershed (Rodrigues et al., 2013).

The slope of the watercourses, determined by the channel gradient, is $10.21 \%$. And the sinuosity index indicates the watercourse tends to be rectilinear. Therefore, the lower deposition of sediments over the channels is also associated with the low slope of the channels (Lana, 2001).

The slope found was $4.74 \%$ and the relief of the watershed was classified as slightly wavy, according to the slope classes and the relief types of Embrapa's Brazilian Soil Classification System (2006).

Low slope is directly related to lower water speed in superficial outflow and higher infiltration, resulting in the water system regulation and regularity in the water production of the watershed (Rodrigues et al., 2013).

The altimetric amplitude of 60 meters is a difference between the maximum and minimum heights, the highest altitude upstream is 680 meters and the lowest altitude downstream is 620 meters, as shown in Table 6 and Figure 3. The average altitude is 650 meters, which is close to the average altitude of the Earth's continents, 623 m (CPRM, 2009).

Table 4 - Physical characteristics of the watershed of Veloso and Café Streams.

\begin{tabular}{|c|c|c|}
\hline Dimensional parameters of the watershed & Unit & Results \\
\hline $\operatorname{Area}(A)$ & $\mathrm{km}^{2}$ & 25.55 \\
\hline Perimeter $(\mathrm{P})$ & $\mathrm{km}$ & 21.37 \\
\hline Width (L) & $\mathrm{km}$ & 7.29 \\
\hline Length $(C)$ & $\mathrm{km}$ & 5.20 \\
\hline Drainage length $(\mathrm{Cr})$ & $\mathrm{km}$ & 23.38 \\
\hline Height length (Cn) & $\mathrm{km}$ & 60.58 \\
\hline Length of the main channel (Cp) & $\mathrm{km}$ & 6.66 \\
\hline Vector distance (Dv) & $\mathrm{km}$ & 4.89 \\
\hline \multicolumn{3}{|l|}{ Relief characteristics of the watershed } \\
\hline Average slope $(D)$ & $\%$ & 4.74 \\
\hline Average altitude $(\mathrm{Hm})$ & $\mathrm{m}$ & 650 \\
\hline Maximum altitude (AM) & $\mathrm{m}$ & 680 \\
\hline Minimum altitude (Am) & $\mathrm{m}$ & 620 \\
\hline Altimetric amplitude of the watershed $(\mathrm{H})$ & $\mathrm{m}$ & 60 \\
\hline Relief ratio $(\mathrm{Rr})$ & - & 0.013 \\
\hline Roughness coefficient (Rn) & - & 4.34 \\
\hline Shape factor $(F f)$ & - & 0.95 \\
\hline Circularity index (Ic) & - & 0.70 \\
\hline Compactness coefficient $(\mathrm{Kc})$ & - & 1.18 \\
\hline \multicolumn{3}{|l|}{ Standard drainage indices of the watershed } \\
\hline Order of the watershed $(w)$ & - & 4th \\
\hline Drainage density $(\mathrm{Dd})$ & $\mathrm{km} \mathrm{km}^{-2}$ & 0.92 \\
\hline Maintenance coefficient $(\mathrm{cm})$ & $\mathrm{m} \mathrm{m}^{-2}$ & 1.09 \\
\hline Extension of the superficial course (Eps) & $\mathrm{m}$ & 457.53 \\
\hline Channel gradient $(\mathrm{Gc})$ & $\%$ & 10.21 \\
\hline Sinuosity index (Is) & - & 1.36 \\
\hline
\end{tabular}




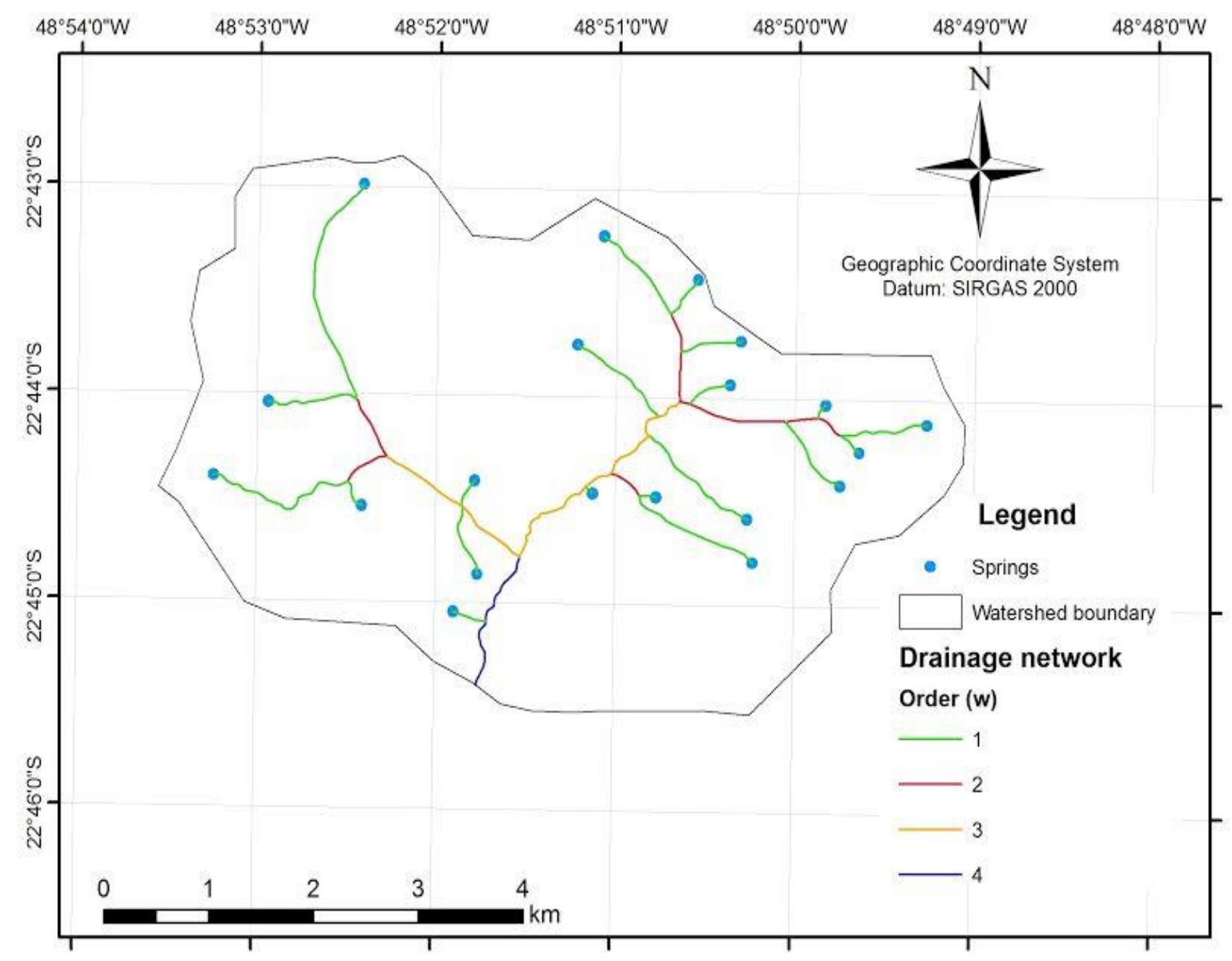

Figure 2 - Order (w) of the drainage network channels of the watershed of Veloso and Café Streams.

Table 5 - Order, amount and length of the watercourses of the watershed of Veloso and Café Streams.

\begin{tabular}{ccc}
\hline Order $(\mathrm{W})$ & Amount & Length $(\mathrm{m})$ \\
\hline w1st & 20 & $14,323.63$ \\
w2nd & 5 & $3,850.01$ \\
w3rd & 2 & $3,885.06$ \\
w4th & 1 & $1,323.90$ \\
\hline Total & 28 & $23,382.60$ \\
\hline
\end{tabular}

Table 6 - Length of the altimetric heights of the watershed of Veloso and Café Streams.

\begin{tabular}{ccc}
\hline Heights $(\mathrm{Cn})$ & Altitude $(\mathrm{m})$ & Length $(\mathrm{m})$ \\
\hline Cn1st & 620 & $6,161.48$ \\
Cn2nd & 640 & $18,937.58$ \\
Cn3rd & 660 & $23,371.08$ \\
Cn4th & 680 & $12,113.25$ \\
\hline Total & 650 & $60,583.39$ \\
\hline
\end{tabular}




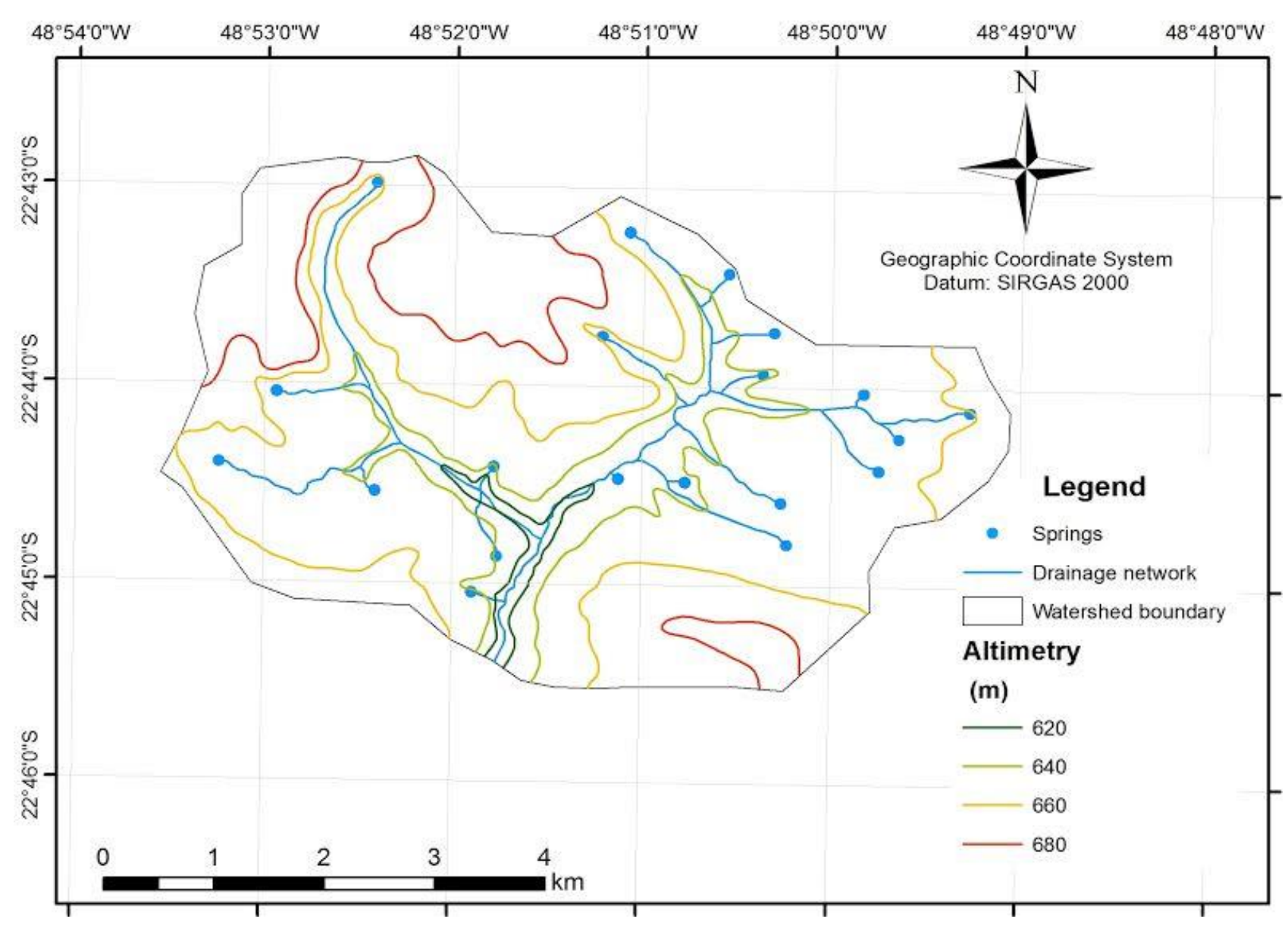

Figure 3 - Altimetry of the watershed of Veloso and Café Streams.

Relief ratio is low, according to Piedade's classification parameters (1980), showing a less rugged terrain in the region, hence, less direct superficial outflow (Qds) of rain water, resulting in higher ratio infiltration-runoff, decreasing erosions (Rodrigues et al., 2013).

According to Rocha's classification (1997), the higher the roughness coefficient is, the greater are the erosion risks. The value of 4.34 , found for the watershed under study, indicates a low roughness coefficient, in which soil is appropriate to agriculture (Class A), due to lower possibility of erosion.

The results of shape factor, circularity index of the watershed and compactness coefficient (Table 4), according to parameters set by Villela \& Mattos (1975), suggest the watershed has round to oval shape, indicating a medium to high tendency to floods and erosion by high rainfall.

\section{Conclusions}

Shape factor, circularity index and compactness coefficient indicate a high to medium tendency to floods by torrential rains.

The low slope and drainage density, together with other morphometric indices (such as maximum altimetric amplitude, relief ratio and rough- ness coefficient), allow us to infer that the watershed has a good ratio infiltration-runoff, reducing the erosion risk associated with slow superficial outflow.

Greater attention to permanent preservation areas (APPs) is recommended, in order to ensure lower external sedimentation and greater protection of riparian ecosystem.

\section{References}

Christofoletti A (1969) Análise morfométrica de bacias hidrográficas. Notícia Geomorfológica 18(9):35-64.

Christofoletti A (1999) Modelagem de Sistemas Ambientais. São Paulo: Edgard Blücher. 236p.

CRPM - Serviço Geológico do Brasil(2009)Referencial disponível em: http://www.cprm.gov.br/publique/cgi/cgilua.exe/sys/st art.htm?infoid=1054\&sid=129. (Acesso em: 26ago. 2014).

Embrapa (2006) Classificação Brasileira de Solos. Referencial disponível em: http://ainfo.cnptia.embrapa.br/digital/bitstream/item/19 350/1/Jacomine.pdf(accessed Ago 26, 2014). 
França GV (1968) Interpretação fotográfica de bacias e redes de drenagem aplicada a solos da região de Piracicaba. 151f. Escola Superior de Agricultura "Luiz de Queiroz", Universidade de São Paulo; Piracicaba (Tese).

Horton RE (1945) Erosinal development of streams and their drainage basin: hydrophysical approach to quantitative morphology. Geological Society of America Bulletin 56(3):275-370.

IBGE - Instituto Brasileiro de Geografia e Estatística (1973) Informação de consulta pública. 1973.

Pinto Junior OB, Rossete AN (2005) Caracterização morfométrica da Bacia Hidrográfica do Ribeirão Cachoeira, MT-Brasil. Revista Eletrônica do Curso de Geografia do Campus Avançado de Jataí - GO. Jataí/GO, (4):38-56.

Lana CE, Alves JM de P, Castro PTA (2001) Análise morfométrica da bacia do rio do Tanque, MGBRASIL. Revista Escola de Minas 54(2):121-126.

Lima WP (1986) Princípios de hidrologia florestal para o manejo de bacias hidrográficas. Piracicaba: ESALQ. 242p.

Machado RAS, Lobão JSB, Vale RMC, Souza APMJ (2011) Análise morfométrica de bacias hidrográficas como suporte a definição e elaboração de indicadores para a gestão ambiental a partir do uso de geotecnologias. Anais XV Simpósio Brasileiro de Sensoriamento Remoto - SBSR, INPE. Curitiba/ PR, $1441 p$.
Piedade GCR (1980) Evolução de voçorocas em bacias hidrográficas do município de Botucatu, SP. 161f. Faculdade de Ciências Agrárias - FCA, Universidade Estadual Paulista, Botucatu (Tese de Livre Docência).

Rocha JSM(1997) Manual de projetos ambientais. Universidade Federal de Santa Maria. 446p.

Rodrigues VA (2004) Morfometria e mata ciliar da microbacia hidrográfica. In: Anais doVIII Workshop em Manejo de Microbacias Hidrográficas, UNESP. Botucatu. p.7-18.

Rodrigues VA, Cardoso LG, Pollo RA, Ré DS, Paissarra TC, Junior RFV (2013) Análise morfométrica da microbacia do Ribeirão das Araras - SP. Revista Científica Eletrônica de Engenharia Floresta 21(1):25-37.

Schumm SA (1956) Evolution of drainage systems and slopes in badlands at Perth Ambory, New Jersey. Bulletin of the Geological Society of America67:597645.

Strahler AN (1957) Quantitative analyses of watershed geomorphology. Transactions of American Geophysical Union 38:913-920.

Villela SM, Mattos A (1975) Hidrologia aplicada. São Paulo: McGraw-Hill. 245p. 